\title{
Economic study on production and marketing of shrimp and prawn seed in Bangladesh
}

\author{
M. S. Islam, M. S. Rahman, M. M. Haque ${ }^{1}$ and S. Sharmin ${ }^{2}$ \\ Department of Agricultural Economics, ${ }^{1}$ Graduate Training Institute and ${ }^{2}$ Department of Rural Sociology, Bangladesh \\ Agricultural University, Mymensingh-2202, Bangladesh. Email: saidurbau@yahoo.com
}

\begin{abstract}
Shrimp farming and related activities contribute significantly to the national economy of Bangladesh. Successful shrimp culture depends mainly on the availability of healthy and quality shrimp seeds. The present study was designed to analyze the production and marketing system of shrimp seed in Bangladesh. A total sample of 80 stakeholders comprising each of 20 operators of bagda and golda hatcheries, and each of 20 shrimp seed traders and faria (bapari) were selected purposively. Data and information mainly on shrimp seed production and marketing were collected for 2009-2010 from Cox's Bazar and Jessore districts depending upon the concentration of hatcheries established for shrimp seed production. In most cases tabular method of analysis and flow diagram were used. The average sizes of bagda and golda hatcheries were 2.6 and 2.9 acres and the corresponding productions were 430 and 250 million PL per year in Cox's Bazar and Jessore districts respectively. Per hatchery per year total costs, gross returns and net returns were Tk 50.2 and 19.6 million; Tk 90 and 56.3 million; and Tk 39.6 and 36.7 million in Cox's Bazar, and Jessore districts respectively. Shrimp seed production is capital intensive and it is risky business. Although shrimp seed production cost is very high but the farm could earn higher profit by ensuring better culture and management. Marketing channel and distribution system of shrimp seed were identified in the present study. Shrimp seed passed from hatcheries to shrimp farmers followed by sequence of intermediaries. Hatcheries directly sell about $80 \%$ shrimp seed to aratdar and rest $20 \%$ to shrimp seed traders but in case of shifting shrimp seed by cargo plane almost all are sold to aratdar in sale centre. The aratdar is a commission agent who has a fixed establishment and helps the traders (beparies) to sell their products and usually charges a fixed commission of Tk 25-30 per $1000 \mathrm{PL}$ sales revenue. However, less number of intermediaries was involved in shrimp seed marketing.
\end{abstract}

Keywords: Shrimp seed production, Stakehold, Involved, Capital investment, Marketing channel

\section{Introduction}

Shrimp farming and related activities contribute significantly to the national economy of Bangladesh. The main areas of contribution are export earning and employment generation for on and off farm activities. Fisheries sector contributes $4.57 \%$ to the Gross Domestic Product (GDP) and shrimp alone contributes about $0.07 \%$ of total export earning (BER, 2010). In 2009-10, Bangladesh earned about Tk 45000 millions by exporting shrimp (SHAB, 2010). Moreover, Bangladesh has about 2.5 million hectares of coastal tidal land under brackish water shrimp culture. Farming area is steadily expanding. But most of the farmers still follow the traditional method and per unit production is very low $(800-1200 \mathrm{~kg} / \mathrm{ha})(\mathrm{BBS}, 2010)$. There are about 0.30 million ha of brackish water areas in Bangladesh of which 250000 ha has brought under shrimp farming (SHAB, 2010). Earlier, most of the farmers practiced wild stock. Now they started to stock shrimp seed produced from Shrimp Seed Farms (SSFs) or hatchery. In this regard, supply of quality shrimp seed to shrimp farmers is very essential for scientific culture and management. For this purpose, Private Shrimp Seed Farms (PSSFs), both for bagda and golda, have developed and established in different areas of Bangladesh. Most of the bagda hatcheries are established in Cox's Bazar and Teknaf, whereas golda hatcheries are concentrated mostly in greater Jessore district. Both for extensive and intensive farming demand for shrimp seed is increasing. There are 58 bagda hatcheries, mostly located in Kolatoli, Cox's Bazar and produced 8000 million shrimp seed (PL) and of this amount only 1000 million of $\mathrm{PL}$ are used in Cox's Bazar district and rest of 7000 million in Khulna region. Again, for producing golda prawn seed, about 35 SSFs are established in greater Jessore district and most of them are privately owned. These are small farms but their productions are sufficient to meet up the demand of the farmers who are producing golda shrimp in the fresh water ponds. Moreover, about 15 million people are involved in different activities of shrimp industry of Bangladesh (SHAB, 2010). The demand for shrimp seeds will be increasing further if it is possible to bring all suitable lands and culturable brackish waterbodies under intensive cultivation. 
Labour employment in this sector has been increasing approximately by $3.5 \%$ annually. Fish production has been increased to 2.7 million metric tons in 2008-09, which was 1.8 million metric tons in 2000-2001 (BER, 2009). During 1980's about 95\% fish spawn used to be collected from natural sources; currently more than 98\% spawn produced in the hatcheries (Islam, et al., 2000). In 2009-10, the highest ever export earning of Tk 45000 million was obtained through export of shrimp.

It is argued that successful shrimp culture depends mainly on the availability of healthy and quality shrimp seeds, the research work, however, on the economics of shrimp seed production was lacking in the past. Earlier, the shortage of shrimp seed was identified by various agencies as one of the main constraints for scientific shrimp culture in Bangladesh (Rahman, 2003). Even the shrimp seeds were imported from Thailand and India which sometimes caused low production due to stocking of poor quality seed. A few empirical studies (Islam and Wahab 2000, Islam, et al. 2004 and Rahman 2003) observed that shrimp production was suffering due to shortage of shrimp seeds. The Shrimp farmers are depended on the hatchery produced seed on the other hand prawn farmers are heavily depended on wild PL. Dependency of wild PL is harming bio-diversity which is the sustainability issue to the international trade of seafood from Bangladesh. However, there are a number of prawn hatchery have been grown on the south west Bangladesh that did not able to attract the farmers. In this context, the economic analysis of hatchery based seed production of both bagda and golda need to be carried out to make necessary recommendations for hatchery owners and farmers. Accordingly, the production practices and the quality of shrimp seed produced and economic status of SSFs need to be studied. Secondly, marketing system and distribution of shrimp seeds to shrimp farmers is important to examine the supply chain and to assess the demand for and availability of shrimp seed to shrimp farmers. Thirdly, impact of inconsistent and inequalities of demand-supply of shrimp seed on shrimp production need to be determined to know the overall condition of shrimp industry. But no study of this nature has been conducted with a reasonably large size of sample and different types of shrimp farming.

Uddin 1998, Miah 2001, Rahman 2003 and Islam, et al 2004 conducted micro-level studies to determine the economic returns from shrimp production but these studies did not assess production and marketing system, and demand for and supply of shrimp seed in Bangladesh. Few socioeconomic studies were conducted on year round shrimp production, alternate shrimp-rice farming and alternate shrimp-salt farming (Islam et al. 2002, Islam et al. 2004) but there is no detailed study that assessed the production and marketing system of shrimp seed in Bangladesh. It may be noted that traditional shrimp farming and to some extent, semi-intensive farming is relatively new gesture in Bangladesh and it expanded rapidly in the last two decades. In this period quality shrimp seed also needed for scientific culture and management but due to unjudicial catching from the sea and coastal areas, collection of shrimp seed declined for the last few years. To bridge this gap in supplying of quality shrimp and prawn seed, sufficient number of private firms or hatchery, both for bagda and golda were established mainly in Cox's Bazar and Jessore districts respectively. Keeping this in view, the present study was designed to analyse the production and marketing system of shrimp seed in Bangladesh.

\section{Materials and Methods}

\section{Selection of stakeholders involved in shrimp seed production and marketing}

Production practices in producing shrimp seed and management of shrimp seed farms (SSFs) is very important to have higher production and economic returns. There are 58 bagda hatcheries and 35 golda hatcheries in Bangladesh. Considering the salinity, most of the bagda hatcheries are established in Cox's Bazar district and very few (4) are in Khulna district. On the other hand, golda hatcheries are mostly located in grater Jessore district and to some extent, other areas in Bangladesh. However, to know the production practices and input used in producing shrimp seed (bagda and golda), operators of bagda shrimp farm (SSF) and golda SSF were selected as shown in Table 1.

For shrimp seed producers and shrimp seed distributors, a total sample of 80 stakeholders comprising each of 20 operators of bagda hatcheries and golda hatcheries, and each of 20 shrimp seed traders and faria (bapari) were selected purposively (Table 1). Shrimp seed traders and faria (bapari), and the related market participants are directly involved with supply chain and marketing system of shrimp seed. All these sample stakeholders were selected depending on concentration and availability in different locations. In selecting these stakeholders, purposive random sampling was followed. 
Table 1. Study design and distribution of stakeholders involved in shrimp seed production and marketing

\begin{tabular}{|l|l|c|}
\hline Stakeholders selected & Study areas & Sample stakeholders \\
\hline 1. Shrim seed producer: & & 20 \\
\hline Operator of bagda shrimp seed farm (SSF) & Cox's Bazar & 20 \\
\hline Operator of golda SSF & Jessore & \\
\hline 2. Shrimp and shrimp seed distributor & & 20 \\
\hline Shrimp seed trader & Cox's Bazar and Jessore & 20 \\
\hline Faria/Bapari marketed shrimp seed & Jessore & $\mathbf{8 0}$ \\
\hline Total & & \\
\hline
\end{tabular}

\section{Data collection and analysis}

The production process and costs incurred for producing shrimp seed aims at making use of primary data which were collected from selected locations depending upon the concentration of hatcheries established for shrimp seed production. Since the SSFs are concentrated in Cox's Bazar and Jessore, both hatcheries and hatchery operators of bagda and golda were selected from these areas. As the shrimp seed production and its stocking suffer from seasonality, data were collected for one year period during 2009-2010.

SSFs were considered as the unit of analysis to determine the production practices and quality of shrimp seed produced in government and private SSFs. Secondly, nurserers and PL trader, as well as faria (bapari) were selected to examine the marketing system and supply chain of shrimp seed. The present study collected data and information mainly on shrimp seed production and marketing. For shrimp seed production and marketing, hatchery operators, and traders involved in marketing channel were identified, and economic returns of shrimp seed production, and marketing participants were determined by using tables and flow diagram. Data were collected from respondents by using semi-structured interview schedule and conducting PRA for group information. In most cases tabular method of analysis was used to determine the cost, returns and profitability of shrimp seed produced and to assess the marketing system and supply chain of shrimp seed.

\section{Results and Discussion}

\section{Shrimp seed production}

Most of the bagda hatcheries are established in Cox's Bazar and those of golda hatcheries are in greater Jessore district. It is evident from Table 2 that average numbers of brood pond/tanks were 50 and 35 in Cox's Bazar and greater Jessore district respectively. On the other hand, the nursery pond/tanks under each hatchery were 40 and 30 in those two areas respectively. Moreover, brood and nursery tanks were very small and those were inside the hatchery complex in both the districts. Nursery tanks were about 2 times larger than those of brood tanks.

Table 2. Identification and particulars of shrimp seed farms

\begin{tabular}{|l|l|c|c|}
\hline \multicolumn{2}{|l|}{ Particulars } & $\begin{array}{c}\text { Bagda hatchery in } \\
\text { Cox's Bazar }\end{array}$ & $\begin{array}{c}\text { Golda hatchery in } \\
\text { greater Jessore }\end{array}$ \\
\hline \multirow{2}{*}{ Brood pond/tank } & No. of pond/tank per hatchery & 50 & 35 \\
\cline { 2 - 4 } & Pond/tank area (decimal) & 0.6 & 0.9 \\
\hline \multirow{2}{*}{ Nursery pond/tank } & No. of pond/tank per hatchery & 40 & 30 \\
\cline { 2 - 4 } & Area/pond (decimal) & 1.0 & 2.12 \\
\hline
\end{tabular}

Labour and capital are the main factors of shrimp seed production. Table 3 shows that the hatchery operator created some employment opportunities in their farms. There were two types of employment such as causal labour and permanent labour. Some technical persons were also engaged to produce shrimp seed. 
Table 3. Manpower and capital investment in shrimp seed production

\begin{tabular}{|l|c|c|}
\hline Particulars & Cox's Bazar & Jessore \\
\hline No. of hatchery surveyed & 20 & 20 \\
\hline Type of shrimp seed produced & Bagda shrimp seed & Golda shrimp seed \\
\hline No. of employees engaged/farm & 76 & 65 \\
\hline Capital invested/farm (in Crore Tk.) & 10.0 & 6.0 \\
\hline
\end{tabular}

Regarding physical characteristics of selected shrimp seed farms (SSFs) it was reported that all the farms were found to be active and productive, and are on-going and in good condition. The average sizes of bagda and golda hatcheries were 2.6 and 2.9 acres respectively. Again, hatchery operators reported that the average productions of these hatcheries were 430 and 250 million per year (Table 4). Production per hatchery in Cox's Bazar was higher (72\%) than that of Jessore district.

Table 4. Physical characteristics of shrimp seed farms (SSFs)

\begin{tabular}{|l|c|c|}
\hline Particulars & Cox's Bazar & Jessore \\
\hline SSF selected, No. & 20 & 20 \\
\hline Area of SSF, Acre & 2.6 & 2.9 \\
\hline Production/farm/year (No. of PL) & 430 million & 250 million \\
\hline
\end{tabular}

\section{Cost of production of shrimp seed}

Usually the shrimp seed producers follow highly sophisticated technology which caused higher production cost for producing bagda and golda shrimp seed. It can be seen from Table 5 that hatchery operator had to bear the cost for artima, poly bag, saline water, transportation, permanent and causal labour, brood shrimp, loss incurred, interest on operating capital, etc. for the production of shrimp seed and its marketing. Most of the hatcheries still employ foreign expert for breeding and producing shrimp seed. Expert's salary is very high which also increased the cost of production of shrimp seed. Above all transportation cost (48.7\%) was the highest among all the costs incurred by the hatchery operator in Cox's Bazar. On the other hand, loss incurred due to damage of seed during transportation was the highest $(47.7 \%)$ of the hatchery operator in Jessore district for producing and selling of golda shrimp seed.

The initial investment is the main issue in hatchery business. It needs about Tk 50 to 100 million to set up a hatchery in a suitable place. The working capital is the secondary issue but it needs about Tk 10 to 50 million per year to maintain all sorts of operating cost of the shrimp seed production and marketing. With incurring this cost the hatchery operators were able to produce on an average 250 and 430 million shrimp seeds (PL) annually (Table 6) in Jessore and Cox's Bazar districts respectively.

Table 5. Cost of production of shrimp seed

Unit/farm/year

\begin{tabular}{|c|c|c|c|c|c|c|c|}
\hline \multirow{2}{*}{\multicolumn{2}{|c|}{ Items/hatchery }} & \multicolumn{3}{|c|}{ Cox's Bazar } & \multicolumn{3}{|c|}{ Jessore } \\
\hline & & Quantity & $\begin{array}{c}\text { Unit } \\
\text { price,Tk }\end{array}$ & Cost, Tk & Quantity & $\begin{array}{c}\text { Unit } \\
\text { price,Tk }\end{array}$ & Cost, Tk \\
\hline \multicolumn{2}{|c|}{ Artima (cartoon) } & 43 & 21500 & $924500(2.4)$ & 33 & 21500 & $709500(5.4)$ \\
\hline \multicolumn{2}{|c|}{ Poly bag (piece) } & 25000 & 8 & $200000(0.5)$ & 20000 & 8 & $160000(1.2)$ \\
\hline \multicolumn{2}{|c|}{ Saline water } & - & - & $50000(0.1)$ & - & - & $40000(0.3)$ \\
\hline \multirow{2}{*}{$\begin{array}{l}\text { Transport } \\
\text { (box) }\end{array}$} & Plane & 37500 & 450 & $16800000(43.8)$ & - & - & - \\
\hline & Track & 87 & 20000 & $1740000(4.5)$ & 160 & 10000 & $1600000(12.2)$ \\
\hline \multicolumn{2}{|c|}{ Permanent labour } & 6 & 60000 & $360000(0.9)$ & 5 & 48000 & $240000(1.8)$ \\
\hline \multicolumn{2}{|c|}{ Electricity + diesel } & - & - & $1500000(3.9)$ & - & - & $1200000(9.2)$ \\
\hline \multicolumn{2}{|c|}{ Causal labour } & 70 & 24000 & $1680000(4.4)$ & 60 & 21000 & $1260000(9.6)$ \\
\hline \multicolumn{2}{|c|}{ Loss incurred } & - & - & $10750000(28.0)$ & - & - & $6250000(47.7)$ \\
\hline \multicolumn{2}{|c|}{ Brood shrimp } & 100 & 8500 & $850000(2.2)$ & 75 & 6000 & $450000(3.4)$ \\
\hline \multicolumn{2}{|c|}{$\begin{array}{l}\text { Interest on operating } \\
\text { capital }\end{array}$} & - & - & $3485450(9.1)$ & - & - & 1190950 (9.1) \\
\hline \multicolumn{2}{|l|}{ Total cost } & & & $38339950(100)$ & & & $13100450(100)$ \\
\hline
\end{tabular}

Figures in the parentheses indicate the percentage of total cost. 
Table 6. Output and capital investment information

\begin{tabular}{|l|c|c|c|c|c|c|}
\hline \multirow{2}{*}{ Items } & \multicolumn{3}{|c|}{ Cox's Bazar } & \multicolumn{3}{c|}{ Jessore } \\
\cline { 2 - 7 } & $\begin{array}{c}\text { No./ } \\
\text { amount, Tk }\end{array}$ & $\begin{array}{c}\text { Unit price, } \\
\text { Tk/PL }\end{array}$ & $\begin{array}{c}\text { Total return } \\
\text { (million Tk.) }\end{array}$ & $\begin{array}{c}\text { No./ } \\
\text { amount, Tk }\end{array}$ & $\begin{array}{c}\text { Unit price, } \\
\text { Tk/PL }\end{array}$ & $\begin{array}{c}\text { Total return } \\
\text { (million Tk.) }\end{array}$ \\
\hline PL & 430 million & 0.21 & 90 & 250 million & 0.23 & 56.3 \\
\hline Initial capital & - & - & 10 & - & - & 6 \\
\hline Working capital & - & - & 40.2 & - & - & 13.6 \\
\hline
\end{tabular}

\section{Costs and returns of shrimp seed production and marketing}

Cost and returns of shrimp seed production are summarized in Table 7. Hatchery operator had to bear two types of cost: fixed cost and variable cost. Total costs were Tk 50.2 and 19.6 million per hatchery per year in Cox's Bazar, and Jessore districts respectively. The gross returns per hatchery per year were Tk 90 and 56.3 million in two districts respectively. The average net returns were Tk 39.6 and 36.7 million respectively. It is seen from Fig. 1 that the gross return in Cox's Bazar hatchery was much higher than that of Jessore district hatchery but due to high transportation cost, the net returns were almost similar in both the hatcheries.

Table 7. Costs and returns in shrimp seed production and marketing

Tk/farm/year

\begin{tabular}{|l|c|c|}
\hline Cost/return & Cox's Bazar (million Tk) & Jessore (million Tk) \\
\hline A. 1. Fixed cost & 10 & 6 \\
2. Variable cost & 40.2 & 13.6 \\
Total cost & 50.2 & 19.6 \\
\hline B. Gross return & 90 & 56.3 \\
\hline C. Net return & 39.8 & 36.7 \\
\hline
\end{tabular}

Cox's Bazar $\square$ Jessore

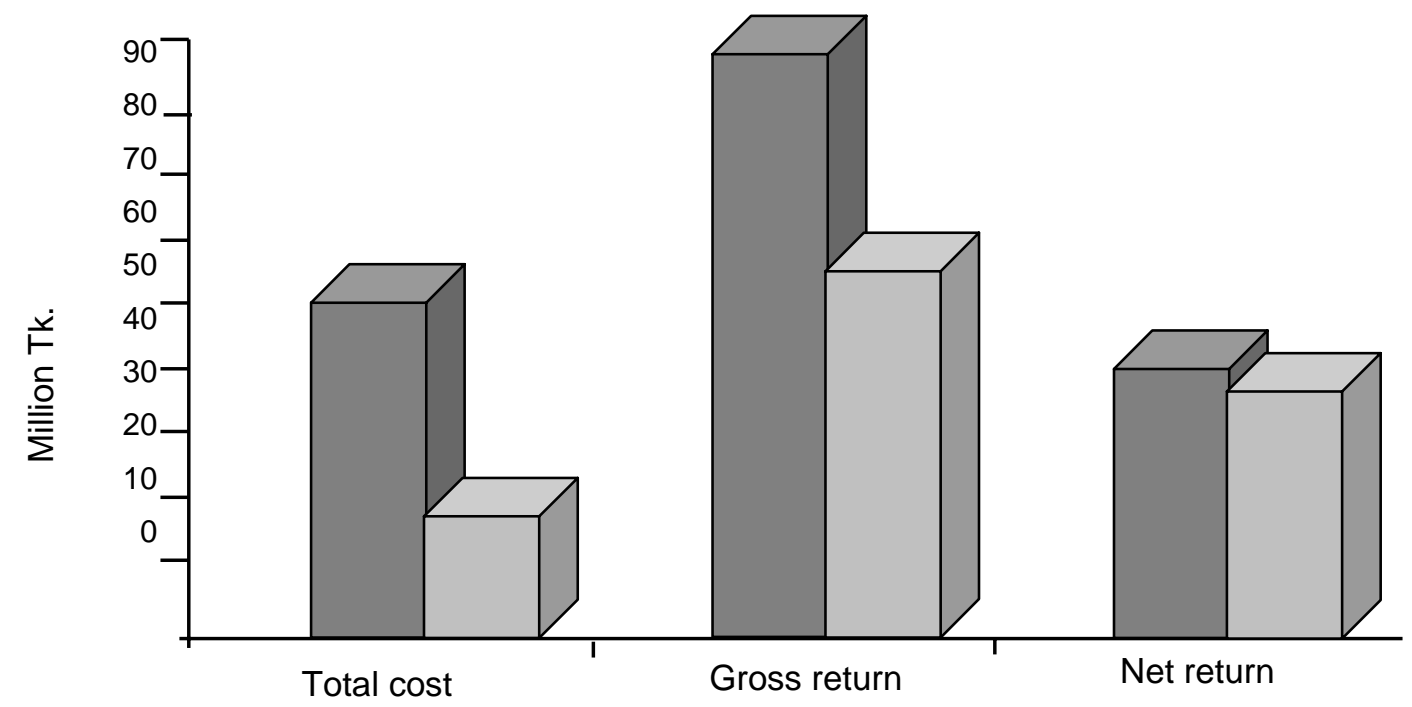

Fig. 1. Total costs, gross returns and net return in fish seed production and marketing 
Transportation costs of shrimp seed is one of the main cost for its marketing and it is evident from Table 8 that airplane, track, microbus, pick up and van, other vehicles were used for transporting shrimp seed from hatchery to gher areas. Hatchery operator in Cox's Bazar had to use airplane to transfer quality seed to Jessore region. This airplane cost was much higher than any other type of costs.

Table 8. Transportation costs of shrimp seed marketing in the study areas

\begin{tabular}{|l|c|c|c|c|}
\hline \multirow{2}{*}{ Means of transportation } & \multicolumn{3}{|c|}{ Estimated transportation cost } \\
\cline { 2 - 5 } & \multicolumn{2}{|c|}{ Cox's Bazar } & \multicolumn{2}{c|}{ Jessore } \\
\cline { 2 - 5 } & No. of PL & Fare, Tk & No. of PL & Fare, Tk \\
\hline Aeroplane (cargo plane) & $6000-8000$ & $450 / \mathrm{bag}$ & - & - \\
\hline Track & $15-20$ lac* & 20000 & $15-20$ lac & 10000 \\
\hline Microbus & $5-6$ lac & 15000 & $5-6$ lac & 6000 \\
\hline Pick up & $10-12$ lac & 18 & $3-4$ lac & 4000 \\
\hline Van & - & - & $10-15$ thou & 1200 \\
\hline
\end{tabular}

*10 lac = 1 million

\section{Shrimp seed marketing channels and supply chain}

For distribution of shrimp seed, direct marketing between hatchery owner and shrimp farmer is rarely practiced. In most cases, SSFs (shrimp seed producers) channel their PL through agents so that they can concentrate their energies on production. Marketing channel is the sequence of intermediaries through which shrimp seed passes from SSFs to shrimp farmer. This channel may be short or long depending on size and quality of shrimp seed marketed, available marketing services and the prevailing social and physical environment. SSFs reported that both bagda and golda shrimp seed produced from hatchery supplied about $95-100 \%$ of shrimp seed demanded by shrimp farmers. In case of bagda shrimp seed, only small percentage of natural seeds are used by the shrimp farmers. The channels of distribution of shrimp seed or PLs (Figs. 2 and 3) show that apart from shrimp seed producers, the market participants were shrimp seed traders, aratdar, nurserers and shrimp farmers and their activities regarding shrimp seed marketing and distribution are presented in the following subsections.

Shrimp seed producers: In Cox's Bazar and other areas of Bangladesh, the owners of SSFs sell their shrimp seed specially PL at the farm gate or premises of the hatchery. Apart from golda, bagda shrimp seeds are commercially produced and large number of farms are involved in this industry, and contributing to a great extent to brackish water aquaculture. Accordingly marketing system of bagda shrimp seed are shown in Figs. 2 and 3.

There are 58 bagda hatcheries (SSFs), mostly established in Cox's Bazar, producing about 8000 million shrimp seed (PL) and of this only 1000 million used by the shrimp farmers in Cox's Bazar and other 7000 million are being supplied to Khulna region through cargo plane and to some extent, by using truck and other vehicle. The shipment of shrimp seed by truck and its distribution and marketing are shown in Fig. 3.

The marketing channel and supply chain of shrimp seed (Fig. 2) indicate that SSFs directly sell about $80 \%$ PL to aratdar and rest $20 \%$ to shimp seed traders (SSTs) but in case of shifting shrimp seed by cargo plane (Fig. 3), almost all are sold to aratdar in sale centre.

It was reported by the shrimp seed producers that usually they collect mother shrimp (brood shrimp) from the deep sea near to Saint Martin Island. In Bangladesh there are 10 - 12 trawlers, privately owned and are available to collect mother shrimp from the deep sea. It is very scarce to collect and accordingly its cost varies from Tk $5000-6000 /$ mother shrimp. Due to scarcity and unavailability, one mother shrimp was sold Tk15000- 20000 in 2010. However, considering all costs, the rate of selling PL was Tk 0.20 0.25 in the farm gate of Cox's Bazar. 


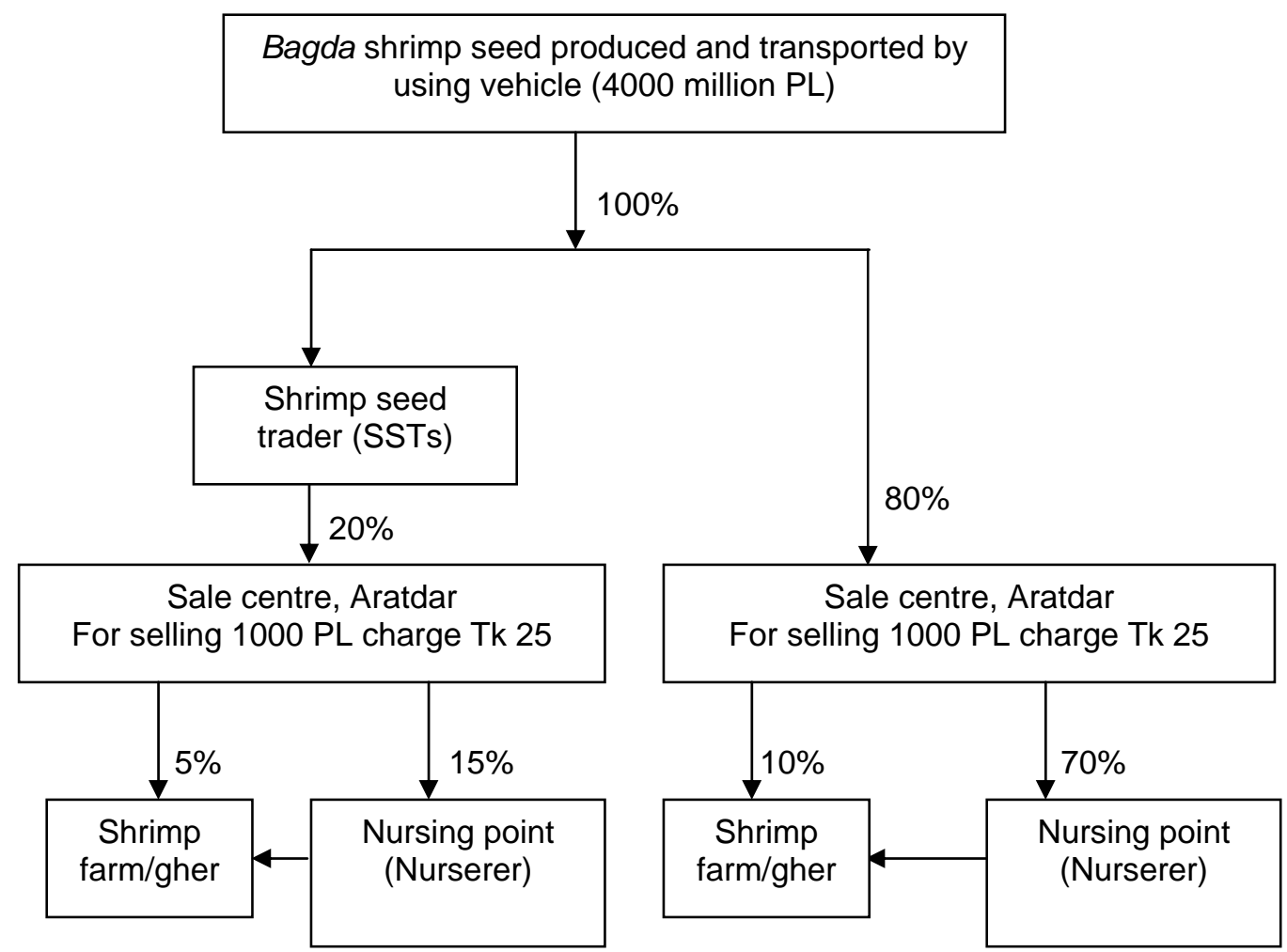

Fig. 2. Marketing channel, supply chain and distribution of bagda shrimp seed

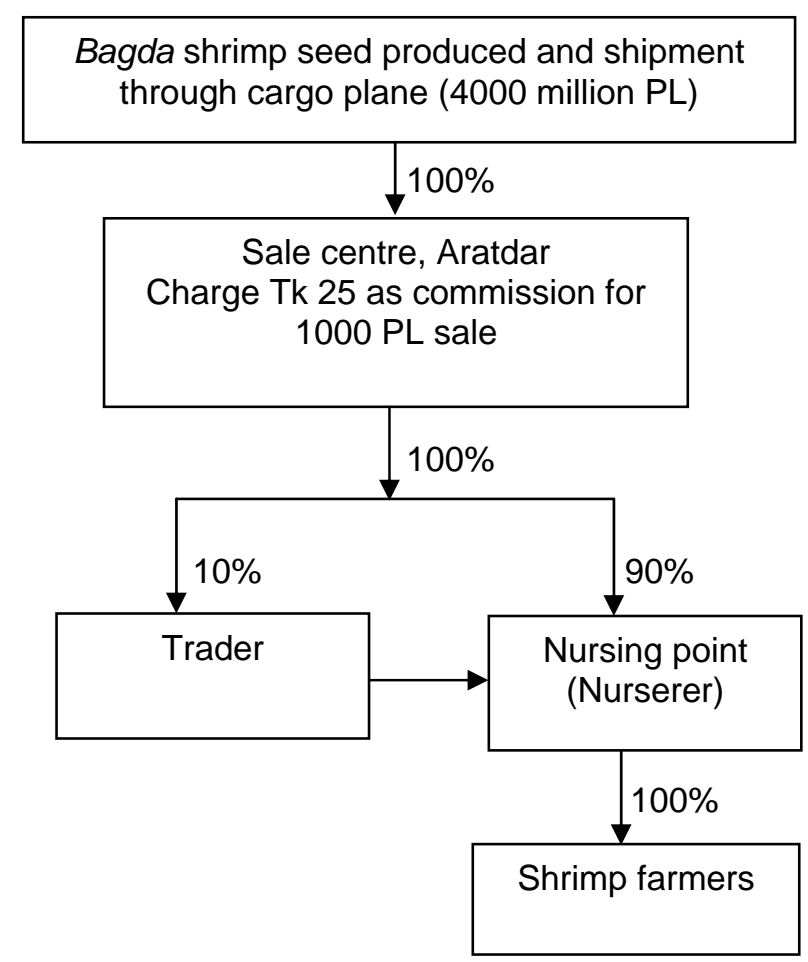

Fig. 3. Shipment and transportation of bagda shrimp seed by cargo plane 
Shrimp seed trader (Beparies): SSTs are involved only in channel 1 (Fig. 2) when seeds are transported by using different vehicle. In shrimp seed marketing, small traders were found to be the professional one and they purchased shrimp seed from producers (SSFs) and sell their consignment to the aratdar or commission agents. Usually, they purchase shrimp seed from the producers and bring them to different sale centre for sale. SSTs are well organized and they were found to handle about $20 \%$ of bagda shrimp seed produced from hatchery. Most of the small traders temporarily employed labourers to be involved in activities in shrimp seed marketing. Traders who purchase shrimp seed (PL) from hatchery and sell it through aratdar and had to pay Tk 25 as commission per $1000 \mathrm{PL}$. It may be noted that about $20 \%$ difference of sales price between shrimp seed producers and traders was observed in the study areas. Fig. 2 shows that $20 \%$ of shrimp seeds were received by the SSTs which were being supplied to aratdar. On the other hand, in case of shipment by cargo plane, small traders purchased only $10 \%$ of shrimp seeds supplied by the aratdar in the sale centre (Fig. 3).

Aratdars: The aratdar is a commission agent who has a fixed establishment and helps the traders (beparies) to sell their products and usually charges a fixed commission of Tk $25-30$ per 1000 PL sales revenue. Since commission is charged on sales revenue, an aratdar tries to sell shrimp seed at higher prices. There are 20 - 35 aratdars in each of Cox's Bazar district and Jessore region to sell shrimp seed to shrimp farmers and nurserers and even to traders (Fig. 2 and 3). They provide facilities for the short period to keep the PL in good condition and then for its shipment. They make cash payment to beparies and supply shrimp seed to shrimp farmers and nurserers, in most cases, on credit. Aratdars do not share any cost of traders (beparies). They hire labourers and salaried persons for performing various functions such as loading, unloading, weighting, grading etc. Usually, they handle larger volume of shrimp seed package than the traders. The aratdars often provide loan to traders on the condition that the small traders have to sell shrimp seed $(\mathrm{PL})$ through them. A trader may take money from more than one aratdars and in this case he divides his products and sells through different aratdars. The traders and aratdars reported that about $70 \%$ of shrimp seed in coastal and brackish water areas is sold by auction through aratdar. The most important aspect of aratdar's business is that, aratdars do not purchase PL but they facilitate to sell the shrimp seed $(\mathrm{PL})$ with the provision of taking commission.

Nurserers: Nurserers play pivoted role in distributing shrimp seed to shrimp farmers. In one sense, they are the distributing agents but in other sense, they also act as producers of shrimp seed. Actually, they prefer to buy PL from aratdar and rear them in their nursery ponds. When PLs raised upto fingerlings stage, they themselves sell it to shrimp farmers. But sometimes, PL traders act as an agent or intermediary who buy PL from aratdars and sell it to shrimp farmers (Fig. 3). Figs. 2 and 3 clearly depicted that more than $80 \%$ of shrimp seeds were distributed through nurserers to shrimp farmers.

Shrimp farmers: The shrimp farmers form the last link in the shrimp seed marketing chain. They buy fingerlings mainly from the nurserers and to some extent, shrimp seed traders to stock in the gher or shrimp farm. In most cases, the nurserers purchase PL from aratdars and make them available to shrimp farmers.

Distribution of shrimp seed by cargo plane: In each year about 8000 million bagda shrimp seeds (PL) are produced in SSFs located in Cox's Bazar and of this amount, 50\% (4000 million PL) are distributed by truck and other vehicle. However, rest 50\% (4000 million PL) shrimp seeds are supplied to Khulna region by using cargo plane. Very few cargo planes are available for shipment and transportation of shrimp seed from Cox's Bazar to Jessore airport. Usually shrimp seed producers (SSP) supply PL to aratdar in sale centre located in Khulna region. Suppliers (SSP) and sometimes aratdars receive consignment in Jessore airport and then bring them to sale centre. As shown in Fig. 3 that, nurserers and traders purchase shrimp seed from aratdar. Usually nurserers rear PL to fingerling stage and then sell it to shrimp farmers. However, shrimp farmers are the ultimate users of shrimp seed. They stock it in their shrimp farm or gher to produce shrimp commercially. 


\section{Conclusion and Recommendations}

The present study included both bagda and golda shrimp to discuss the production and marketing of shrimp seed in Bangladesh. Usually, bagda shrimps are cultured and produced in brackish water and those of golda shrimps are in freshwater. In producing shrimp seed, large number of hatcheries (SSFs) mostly privately owned, were established mainly in Cox's Bazar and Jessore districts. For establishing bagda and golda hatchey, respectively Tk 100 and 60 million initial capital were invested and their corresponding working capital were Tk 38.3 and 13.1 million. However, from the results of the study, following conclusions are made:

- Shrimp seed production is capital intensive and it is risky business because the survival of PL depends on many other things.

- Due to unavailability of in country technical hand, still foreign experts are employed to produce shrimp seed.

- Production cost is very high but the hatchery can earn higher profit by ensuring better culture and management to produce PL and marketing it.

- Less number of intermediaries are involved in shrimp seed marketing and due to that shrimp farmers could have shrimp seed in lower price.

- Shrimp seeds are produced in Cox's Bazar but about 80-90\% shrimp seeds are used in Khulna region. So, it involved lot of marketing cost to carry it from Cox's Bazar to Khulna region.

\section{References}

BBS. 2010. Statistical Pocket Book of Bangladesh, Bangladesh Bureau of Statistics (BBS), Planning Division, Ministry of Planning, Government of the People's Republic of Bangladesh.

BER. 2009 and 2010. Bangladesh Economic Review (BER) 2007. Economic Adviser's Wing. Finance Division, Ministry of Finance. Government of the People's Republic of Bangladesh.

Islam, M.S. and Wahab, M.A. 2000. Socioeconomic and Environmental Impact of Shrimp Farming in Bangladesh. A PRA of two selected villages in Khulna and Cox's Bazar District. Prepared for BAURES-NORAD Project, BAU, Mymensingh.

Islam, M.S., Talukder, R.K. and Miah, A.A. 2004. An Analysis of Stakeholder Profiles in Relation to Production, Marketing and Processing of Shrimp in Bangladesh. Bangladesh Journal of Political Economy, 20(1): 23-40

Islam, M.S., Wahab, M.A. and Miah A.A. 2002. Socioeconomic and Environmental Impacts of Alternate Shrimp-Crop Farming in Bangladesh. The Bangladesh Journal of Agricultural Economics, 25(1): 63-76.

Miah, A.A. 2001. "An Economic Study on Alternate Shrimp-Crop Farming in Coastal Areas of Bangladesh". M.Sc. Thesis submitted to the Department of Agricultural Economics, BAU, Mymensingh.

Rahman, M.H. 2003. "An Economic Study of Golda Shrimp Farming in Selected Areas of Jessore District". M.Sc. Thesis submitted to the Department of Agricultural Economics, BAU, Mymensingh.

SHAB. 2010. Shrimp Hatchery Association of Bangladesh, 17/B SHAB House, Saikat Residential Area, Kalatoli Road, Cox's Bazar, Bangladesh.

Uddin, M. Jamal. 1998. "An Economic Study of Shrimp Farming under Different Types of Cultural and Management Practices in Cox's Bazar District" in Bangladesh". M.Sc. Thesis submitted to the Department of Agricultural Economics, BAU, Mymensingh. 